Egyptian Journal of Aquatic Biology \& Fisheries

Zoology Department, Faculty of Science,

Ain Shams University, Cairo, Egypt.

ISSN $1110-6131$

Vol. 22(5): 537-550(2018)

www.ejabf.journals.ekb.eg

\title{
Potential applications of some moderate halophilic bacteria
}

\author{
Mohamedin, A. H.; Mowafy, A.M*, Elsayed, A.A. and Ghanim, S. O. \\ Botany Department, Faculty of Science, Mansoura University, Mansoura, Egypt \\ *Corresponding author: ammr79@ mans.edu.eg
}

\section{ARTICLE INFO \\ Article History: \\ Received:Nov. 11, 2018 \\ Accepted:Dec. 30, 2018 \\ Online:Jan. 2019}

\section{Keywords:}

Halophiles

Mediterranean sea

PiscibacillusIsh

Piscibacillus Pink

Piscibacillushalophilus

bioremediation

hydrocarbon

\begin{abstract}
The characteristics of halophiles made them a target for employing in several industrial processes. In this study, four moderate halophilic bacteria isolates have been isolated from the northern coast of Mediterranean sea in Egypt. These isolates have been identified according to their 16S rRNA sequence analysis and submission on Genbank-NCBI as Piscibacillus Ish and Piscibacillus Pink with close relevance to Piscibacillus halophilus, Bacillus $C s$ with close relevance to Bacillus aquimaris and Halomonas $C b$ with close relevance to Halomonas merediana. The isolates Piscibacillus Ish and Halomonas $\mathrm{Cb}$ showed remarkable potential to produce lipase in addition to their ability to degrade the used engine oil. The isolate Piscibacillus Ish showed the higher growth on the oil and the lower weight of residual oil than the isolate Halomonas $\mathrm{Cb}$ and the GC-MS analysis of the digested oil sample showed that the amount of certain hydrocarbons such as $\mathrm{C}_{19}, \mathrm{C}_{21}, \mathrm{C}_{27}, \mathrm{C}_{28}$ and $\mathrm{C}_{39}$ have been reduced drastically on day 20 by a percentage of $71.83 \%$, $78.67 \%, 62.21 \%, 74.60 \%$ and $91.95 \%$ respectively. The disappearance of hydrocarbon fractions; $\mathrm{C}_{7}, \mathrm{C}_{15}$ and $\mathrm{C}_{35}$ on day 20 suggests that these may be saturated linear alkanes, so they are easily degraded or fragmented into shorter fractions. All the isolates also were capable of degrading an industrial textile dye called Indigo dye with different degrees and the highest isolate was Halomonas $\mathrm{Cb}$. The obtained results in this study indicated the ability of the studied moderate halophile Piscibacillus Ish to be used in petroleum and used engine oil degradation and the ability of the studied moderate halophile Halomonas $\mathrm{Cb}$ to be used in bioremediation of effluents produced from textile industries contaminated with Indigo dye.
\end{abstract}

\section{INTRODUCTION}

Extremophiles are organisms that are able to survive and grow in extreme environment and are widely distributed in natural habitats. Halophiles are the group of salt loving microorganisms present in saline habitats. Hypersaline environments are spreading all over the world, in arid, coastal and deep sea locations, underground salt mines, and artificial salterns (DasSarma \& DasSarma, 2012).

Different groups of halophilic microorganisms based on the optimal salt concentrationwere defined according to the classification of Kushner (1988) to four groups. The first is the non-halophilic organisms which defined as those requiring less than $1 \% \mathrm{NaCl}$, whereas the second are the halotolerant microorganisms which can tolerate high salt concentrations, this group contains slight halophiles (marine bacteria), growing optimally in media with $1 \%$ to $3 \% \mathrm{NaCl}$. 
The third is the moderate halophiles, which growing optimally in media with $3 \%$ to $15 \% \mathrm{NaCl}$, and the forth are extreme halophiles, which growing optimally in media containing $15 \%$ to $30 \% \mathrm{NaCl}$.

Halophiles and their enzymes could be employed in industrial processes that contain high salt concentrations where the halophiles enzymes exhibit optimal activities at this salt concentration. Enzymes from moderate halophiles usually show high stability under extreme conditions, which give them potential applications in harsh industrial processes (Oren, 2002). Lipase (E.C.3.1.1.3) is an important enzyme catalyzes breakdown of triacylglycerol to glycerol and fatty acids when absorbed to oil-water interface (Martinelle, et al., 1995). Lipases are widely used in fat/oil processing, detergent formulation, paper-pulp industries, food industries, cosmetics and pharmaceuticals (Rubin \& Dennis, 1997) polyurethane (Kumar et al., 2012) and biodegradation of fatty acid containing waste (Takamoto et al., 2001). Halophilic microorganisms considered to be a potential source of commercial halotolerant lipases (Sánchez-Porro et al., 2003). Biodegradation of hydrocarbons and fatty acids derived from petroleum compounds is among the important application of halophiles. Bioremediation of hypersaline environments can only be accomplished using halophilic microorganisms capable of petroleum compounds degradation, because conventional microbiological processes do not function well at elevated salinities (Fathepure, 2014).

One of the most pressing environmental problems related to dye effluents is the improper disposal of wastewater from dyeing industry. The color removal by conventional treatment methods lead to severe water pollution that leads to use the cost effective clean-up operations. These effluents are highly saline with typical salt concentrations of 15-20\%. Microbial degradation seems to be promising compared to other organisms and the method of application are simpler compared to other available methods (Rajeswari et al., 2011). Moderate halophiles such as Salinicoccus iranensis and Halomonas species have been isolated from wastewaters for their ability to decolorize azo dyes and use phenol as a main source of carbon and energy (Guo et al., 2008; Zhao et al., 2017). Indigo dye is an organic compound with a distinctive blue color (Venkatachalam et al., 2013). Historically, indigo was a natural dye extracted from the leaves of certain plants, and this process was important economically because blue dyes were once rare. A large percentage of indigo dye produced today, several thousand tonnes each year, is synthetic. It is the blue often associated with denim cloth and blue jeans.

This study aimed to isolate, identify and characterize bacteria of halophilic nature from the Egyptian habitats in order to open the door for their afro-mentioned biotechnological applications.

\section{MATERIALSANDMETHODS}

\section{Isolation of halophilic bacteria}

Samples from water and soil were collected in sterilized containers in November 2014 from the salt marches of the northern coast of the Mediterranean Sea in Egypt (Gamasa city) and transferred to the laboratory. In order to enrich the isolates, $1 \mathrm{gm}$ soil sample was added to $100 \mathrm{ml}$ modified saline liquid media (SW) containing (10\% NaCl and $0.5 \%$ yeast extract in $100 \mathrm{ml}$ sea water) (Coronado, et al., 2000) and the $\mathrm{pH}$ was adjusted to 7.5. The antifungal (Mycostatin) $250 \mu \mathrm{l}$ was added after autoclaving in order to get rid of fungal growth. The incubation was performed at $37^{\circ} \mathrm{C}$ and $170 \mathrm{rpm}$. Within 3-4 days and after the turbidity appeared, 
serial dilution was carried out and inoculation was done on SW solid media. Compound streaking method was done from different colonies appeared on the same solid media to confirm purification (Amoozegar et al., 2009). Gram stain was done with the modified method of (Dussault, 1955) to suit these isolates. The obtained isolates were preserved as glycerol stocks at $-20^{\circ} \mathrm{C}$ till use.

\section{Growth potential in different $\mathrm{NaCl}$ concentrations:}

For each of the obtained isolates, growth was monitored on SW medium having $0,3,13,18,23$ and $30 \%(\mathrm{w} / \mathrm{v}) \mathrm{NaCl}$, supplemented with $0.5 \%$ yeast extract per 100 $\mathrm{ml}$ seawater. The same medium with $13 \%$ salts was used for the maintenance of the isolates. The growth rate was estimated by inoculating $1 \mathrm{ml}$ of a suspension of the strain, pre-grown to the medium at specific salt concentration. The optical density was measured at $600 \mathrm{~nm}$ after 7 days of incubation at $37^{\circ} \mathrm{C}$ and $150 \mathrm{rpm}$ (RodriguezValera et al., 1980).

Biochemical characterization of the obtained isolates:

Screening for production of hydrolytic enzymes:

Screening for amylase activity:

The presence of amylolytic activity on plates was determined qualitatively using the method described previously using the modified starch agar medium (1\% $(\mathrm{w} / \mathrm{v})$ soluble starch, $0.2 \%(\mathrm{w} / \mathrm{v})$ yeast extract, $0.5 \%(\mathrm{w} / \mathrm{v})$ peptone, $10 \%(\mathrm{w} / \mathrm{v}) \mathrm{NaCl}$, $0.01 \% \mathrm{CaCl}_{2}, 2 \%(\mathrm{w} / \mathrm{v})$ agar dissolved in $100 \mathrm{ml}$ sea water). After incubation at $37^{\circ} \mathrm{C}$ for 3days, the plates were flooded with Grams Iodine Gram's iodine solution; a clear zone around the growth indicated the hydrolysis of starch (Rohban et al., 2009).

Screening for cellulase activity:

Pure cultures of bacterial isolates were individually transferred to modified carboxymethyl cellulose (CMC) agar plates media (1\% (w/v) CMC, $0.03 \%(\mathrm{w} / \mathrm{v})$ $\mathrm{NaNO}_{3}, 10 \%(\mathrm{w} / \mathrm{v}) \mathrm{NaCl}, 1.2 \%(\mathrm{w} / \mathrm{v})$ agar dissolved in $100 \mathrm{ml}$ of sea water). After incubation for 7 days, CMC agar plates were flooded with $0.05 \%$ Congored and allowed to stand for $15 \mathrm{~min}$. at room temperature. One molar $\mathrm{NaCl}$ solution was thoroughly used for counter staining the plates. Clear zones were appeared around growing bacterial colonies indicating cellulose hydrolysis (Irfan et al., 2012).

\section{Screening for protease activity:}

A qualitative screening for the proteolytic activity of the isolates was indicated by growth and clear zones appearance on modified casein agar media $(1 \%(\mathrm{w} / \mathrm{v})$ casein, $0.4 \%(\mathrm{w} / \mathrm{v})$ yeast extract and $2 \%(\mathrm{w} / \mathrm{v})$ agar per $100 \mathrm{ml}$ of sea water) and incubation in $37^{\circ} \mathrm{C}$ for 3days (Mohamedin, 1999).

\section{Screening for lipase activity:}

For qualitative screening for lipase activity, Tween agar medium was used (1\% (w/v) pepton, $10 \%(\mathrm{w} / \mathrm{v}) \mathrm{NaCl}, 0.01 \%(\mathrm{w} / \mathrm{v}) \mathrm{CaCl}_{2} \cdot \mathrm{H}_{2} \mathrm{O}, 2 \%(\mathrm{w} / \mathrm{v})$ agar dissolved in $100 \mathrm{ml}$ were sea water). After autoclaving, we added $1 \mathrm{ml}$ of Tween 20 and 80 while the media is still hot. Tween 80 is used for the detection of lipases as it contains esters of oleic acid, whilst Tween 20 is used for esterase as it contains esters of lower chain fatty acids (Ramnath et al., 2017).The presence of lipolytic enzyme wasdemonstrated by the formation of conspicuoushalos. This is due to the formation of precipitates ofcalcium laurate, palmitate, stearate, or oleatearound the zones of bacterial growth (Gutiérrez \& González, 1972).

\section{Molecular identification of isolated lipase producing halophiles}

The isolates showed the ability to produce lipase were identified by sequencing according tothe protocol of MicroSeq ${ }^{\circledR} 500$ 16S rRNA Bacterial Identification Kits. 


\section{Polymerase Chain Reaction (PCR)}

The bacterial genomic DNA of each strain was isolated using the PrepMan ${ }^{\mathrm{TM}}$ Ultra SamplePreparation Reagent (PN 4322547) by adding $100 \mu 1$ of the sample preparation reagent to appropriate amount of cells. The mixture was vigorously mixed by vortex and incubated in a heat block at $95^{\circ} \mathrm{C}$ for 10 minutes and then allowed to cool to room temperature for 2 minutes. The tubes were entered to the microcentrifuge at $10000 \mathrm{rpm}$ for 2 minutes, and then the supernatant was used as template. The genomic DNA was used as a template for PCR amplification of the $16 \mathrm{~S}$ rRNA gene using the 9700 thermal cycler. PCR was performed using the forward primer5'-AGTTTGATCATGGTCAG-'3andreverseprimer

5

GGTTACCTTGTTACGACT-'3 (Sanchez-Porro et al., 2007). The thermal cycler was programmed as follow: $95^{\circ} \mathrm{C}$ for $20 \mathrm{~min}, 95^{\circ} \mathrm{C}$ for $30 \mathrm{sec}, 60^{\circ} \mathrm{C}$ for $30 \mathrm{sec}, 72^{\circ} \mathrm{C}$ for $45 \mathrm{sec}$, and $72^{\circ} \mathrm{C}$ for $10 \mathrm{~min}$ ( 30 cycles). The PCR product of each of the tested isolates was purified by Montage PCR filter unit (Millipore PN UFC7 PCR50) and confirmed to present in samples by running a $2 \%$ agarose gel.

\section{Sequencing of the 16S rRNA gene of the isolates}

The sequencing reactions were performed in the 9700 thermal cycler at a total volume of $20 \mu 1$ ( $7 \mu 1$ of the purified PCR product and $13 \mu 1$ of the sequencing module) by adjusting thermal cycler conditions to $96^{\circ} \mathrm{C}$ for $10 \mathrm{sec}, 50^{\circ} \mathrm{C}$ for $5 \mathrm{sec}$ and $60^{\circ} \mathrm{C}$ for $4 \mathrm{sec}(25$ cycles $)$. Then the excess dye terminators and primers were removed from the cycle sequencing reaction using Dye $\mathrm{Ex}^{\mathrm{TM}}$ 2.0 Spin Kit (Qiagen PN 63204).

The generated sequenceswere analyzed by Finch TV (version 1.4.0) software and the phylogenetic tree was generated via Seaviewsoftware using the closest published type strains sequences. In this study, sequences of the obtained isolates were submitted to the GenBank on NCBI.

\section{Quantitative assay of lipase Preparation of crude enzyme:}

The obtained isolates gave positive lipase activity were inoculated in a liquid media containing $0.5 \%(\mathrm{v} / \mathrm{v})$ olive oil, $0.025 \% \mathrm{CaCl}_{2}, 0.2 \%$ yeast extract, $10 \% \mathrm{NaCl}$ in sea water and Incubated for 7 days in $37^{\circ} \mathrm{C}$ and $170 \mathrm{rpm}$. After centrifugation at $6000 \mathrm{rpm}$ for 15 minutes in $4^{\circ} \mathrm{C}$, the obtained supernatant was regarded as a source of the enzyme (Khunt \& Pandhi, 2012). The enzyme preparation was added to an assay mixture containing $10 \mathrm{ml}$ of the substrate $(10 \%(\mathrm{w} / \mathrm{v})$ homogenized oliveoil emulsified in $10 \%(\mathrm{w} / \mathrm{v})$ gum acacia), $0.6 \mathrm{mM} \mathrm{CaCl}_{2}, 50 \mathrm{mM}$ of potassium phosphate buffer $\mathrm{pH}$ 7.1. The reaction was started by adding the enzyme preparation and incubated at $37^{\circ} \mathrm{C}$ and terminated by adding the solvent mixture acetone: ethanol (1:1). A part of the assay mixture was obtained at zero time, after 10, 20 and 30 minutes and it was titrated against $50 \mathrm{Mm} \mathrm{NaOH}$ after termination as mentioned previously.

Lipase activity is defined as the amount of enzyme that librates $1 \mu \mathrm{mol}$ of fatty acid per minute under the specified assay conditions. Lipase activity was calculated using the following equation:

\footnotetext{
Lipase activity $(\mathrm{U} / \mathrm{ml})=\frac{(\mathrm{ml} \mathrm{NaOH} \text { for sample }-\mathrm{ml} \mathrm{NaOH} \text { for blank }) x \text { Molarity of } \mathrm{NaOH} X 1000}{\text { value of sub sample } x \text { time }}$
}

\section{Effectof different nitrogen sources in production media of lipase on lipase activity}

Two different nitrogen sources were used in production medium one time with $0.2 \%(\mathrm{w} / \mathrm{v})$ yeast extract as an organic nitrogen source and the other with $0.2 \%(\mathrm{w} / \mathrm{v})$ $\mathrm{KNO}_{3}$ as an inorganic nitrogen source and the $\mathrm{pH}$ was adjusted at 7.5 
(Sivasubramaniet al., 2013). The lipase activity of different isolates was measured by the previous method after 7 days of incubation in $37^{\circ} \mathrm{C}$ and $170 \mathrm{rpm}$.

Time course of lipase activity "Growth versus lipase activity"

Activity of the crude lipase enzyme and the growth of highest lipase producing isolates on the culture were monitored for the productive isolates (Ish and $\mathrm{Cb}$ ) for seven days. Culture broths were collected every day for seven days and growth was measured spectrophotometrically at O.D. $600 \mathrm{~nm}$ and lipase activity was measured as mentioned before ( $\mathrm{Li} \& \mathrm{Yu}, 2012$ ).

\section{Biodegradation of the used engine oil:}

A basal medium of $0.2 \%$ yeast extract, $0.04 \% \mathrm{CaCl}_{2} \cdot 2 \mathrm{H}_{2} \mathrm{O}, 10 \% \mathrm{NaCl}$ and $1 \%$ used cars oil in $100 \mathrm{ml}$ sea water was prepared. In order to enhance the degradation of used engine oil hydrocarbons, $0.05 \%$ Tween 80 was added to the culture medium as a synthetic surfactant. The medium was further inoculated with $1 \mathrm{ml}$ of isolate that gave the highest quantitative lipase activity and then incubated at $37^{\circ} \mathrm{C}$ and $150 \mathrm{rpm}$. Residual oil was extracted by adding $10 \mathrm{ml}$ hexane and shaking thoroughly as described previously (Obayori et al., 2009). After removing the aqueous phase with separating funnel, the residual oil was weighed and the concentration of hydrocarbon fractions was determined by gas chromatography and the O.D. of aqueous phase was measured by spectrophotometer at $600 \mathrm{~nm}$ similarly, a medium passed through all afro-mentioned components except the inoculation was also extracted in order to serve as a control.

Hewlett Packard 5890 Series II gas chromatograph equipped with flame ionization detector (FID) and $30 \mathrm{~m}$ long HP-5 column (internal diameter, $0.25 \mathrm{~mm}$; film thickness, $0.25 \mu \mathrm{m})$ was used to analyze the hexane extracts $(1.0 \mu \mathrm{l})$ and nitrogen was the carrier gas. The temperature of injector and detector was maintained at $250^{\circ} \mathrm{C}$ and $350^{\circ} \mathrm{C}$ respectively. The initial temperature of column was programmed at $70^{\circ} \mathrm{C}$; this was held for $2 \mathrm{~min}$, then ramped at $10^{\circ} \mathrm{C} / \mathrm{min}$ to $320^{\circ} \mathrm{C}$ and held for 10 minutes (Obayori et al., 2014). Wiley275 and NIST05 mass spectral databases were used in the identification of the separated peaks.

\section{Textile dye degradation test}

In $100 \mathrm{ml}$ Erlenmeyer flask, $50 \mathrm{ml}$ of the following media were prepared (1\%) $\mathrm{v} / \mathrm{v})$ Indigo dye, $0.2 \%(\mathrm{w} / \mathrm{v})$ yeast extract, $10 \%(\mathrm{w} / \mathrm{v}) . \mathrm{NaCl}$ dissolved in $100 \mathrm{ml}$ seawater and their $\mathrm{pH}$ was adjusted to 7.5 using $1 \mathrm{~N} \mathrm{NaOH}$, autoclaved and each one inoculated by one colony of each isolate and incubated at $37{ }^{\circ} \mathrm{C}$ with $170 \mathrm{rpm}$ orbital shaking(Le Borgne et al., 2008). This experiment was repeated using the inorganic nitrogen source $\left(\mathrm{NaNO}_{3}\right)$ instead of yeast extract.

After 15 days, $3 \mathrm{ml}$ of each flask was centrifuged at $40000 \mathrm{rpm}$ for 15 minutes to isolate the bacterial mass. The de-colorization was monitored at $550 \mathrm{~nm}$. Then, degrading activity of isolate was determined by measuring the decrease in blue color by spectrophotometer and control medium was used as standard. The percentage of de-colorization was calculated according to the formula (Mounguengui et al., 2014);

$$
\text { Decolorization }(\%)=\frac{(\text { initial absorbance }- \text { observed absorbance }) x 100}{\text { initial absorbance }}
$$

\section{RESULTS}

\section{Isolation of the halophilic bacteria:}

Out of sixteen different bacterial isolates, four of them gave positive lipase activity and those were morphologically and biochemically characterized and molecularly identified by $16 \mathrm{~S}$ rRNA analysis. It was noticed that the color of the 
isolate named (pink) changed on medium plate from whit to pink then to red color. The color of isolate Ish changed from pink to red color. The color of $\mathrm{Cs}$ and $\mathrm{Cb}$ isolates were deep cream and cream respectively (Table 1). Beside Lipase activity, all isolates show cellulase and protease activities. Amylase activity was missing in Pink and Cs isolates. Table 1 shows the response of different isolates to different salt concentrations. None of the obtained isolates showed an observable growth in presence of $30 \% \mathrm{NaCl}$. However, most of them showed their highest growth in response to $13 \% \mathrm{NaCl}$ indicating that the obtained isolates are mostly moderate halophiles.

Table 1: Biochemical and morphological characterization of the obtained isolates.

\begin{tabular}{|l|c|c|c|c|}
\hline \multirow{2}{*}{ Characteristics } & \multicolumn{3}{c|}{ The obtained isolates with lipase activity } \\
\cline { 2 - 5 } Colony color & Ish & Pink & Cb & Cs \\
\hline Motility & pink turns red & $\begin{array}{c}\text { white turns pink } \\
\text { then red }\end{array}$ & Cream & Deep Cream \\
\hline Gram stain\& cell shape & + & + & + & + \\
\hline Lipase & Gram +ve rod & Gram +ve rod & Gram -ve rod & Gram +ve rod \\
\hline cellulase & + & + & + & + \\
\hline Amylase & + & + & + & + \\
\hline Protease & + & + & + & + \\
\hline $\begin{array}{l}\text { Salinity range for growth }(\mathbf{N a C l} \%(\mathbf{w} / \mathbf{v})) \\
\text { Optimal salinity (NaCl \% }(\mathbf{w} / \mathbf{v}))\end{array}$ & +23 & + & + & + \\
\hline
\end{tabular}

\section{Molecular identification of the selected isolates}

The four selected isolates were molecularly identified via analyzing the sequence of the $16 \mathrm{~S}$ rRNA gene. The obtained sequence for each of them was compared to type strainsobtained from the Ribosomal Database Project (RDP) using sequence match tool and usingthe BLAST program in the GenBank database in the National Center for Biotechnology Information (NCBI). The 16S rRNA sequence of isolates Ish and Pink showed high levels of sequence similarity with Piscibacillus halophilus $(99.8 \%, 99.1 \%)$ respectively. On the other hand, $\mathrm{Cb}$ and $\mathrm{Cs}$ showed a very high sequence identity to Halomonas merediana (93.3\%) and Bacillus aquimaris $(99.2 \%)$ respectively. The $16 \mathrm{~S}$ rRNA sequence of the isolates Ish, Pink , Cb, and Cs were submitted to Gene bank with accession numbers MH591116, MH591115 , MH591117 and MH591118 respectively as shown in Figures 1, 2 and 3.

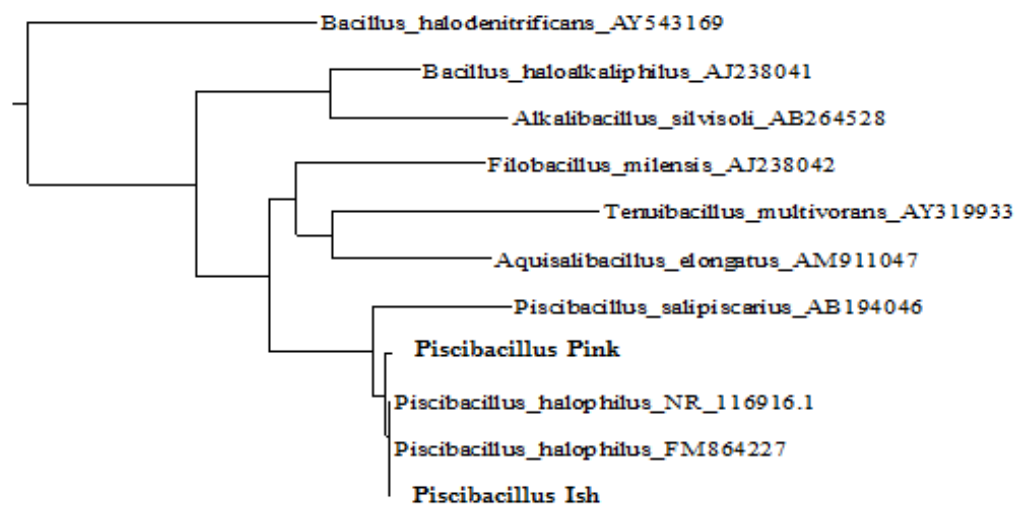

Fig. 1: Phylogenic tree of the isolates Ish and Pink based on 16S rRNA gene sequences using distance method. 


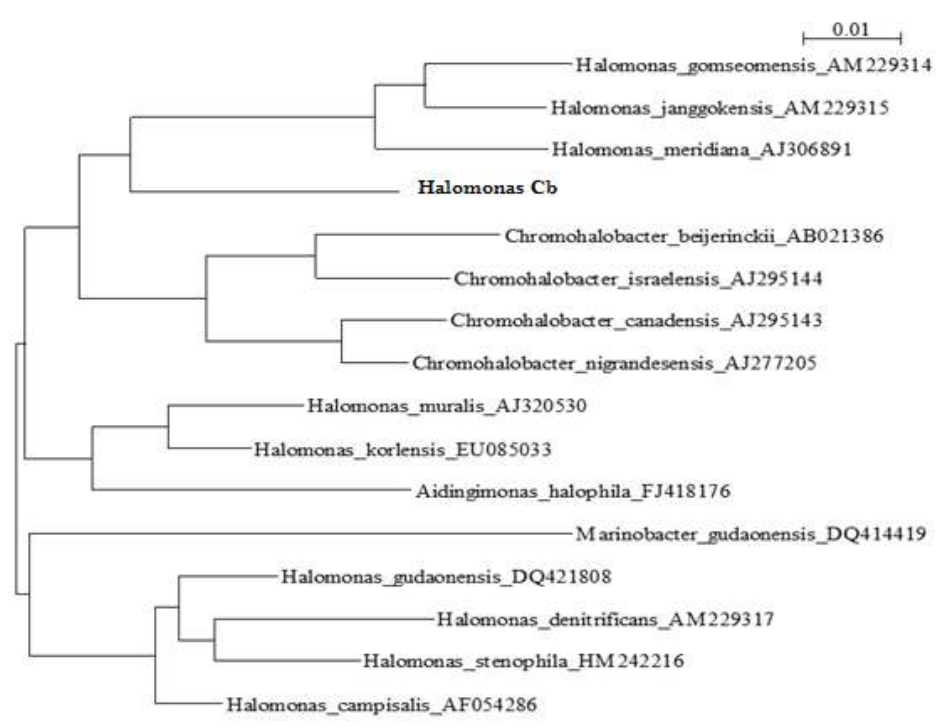

Fig. 2: Phylogenic tree of the isolate $\mathrm{Cb}$ based on full 16S rRNA gene sequences using distance method.

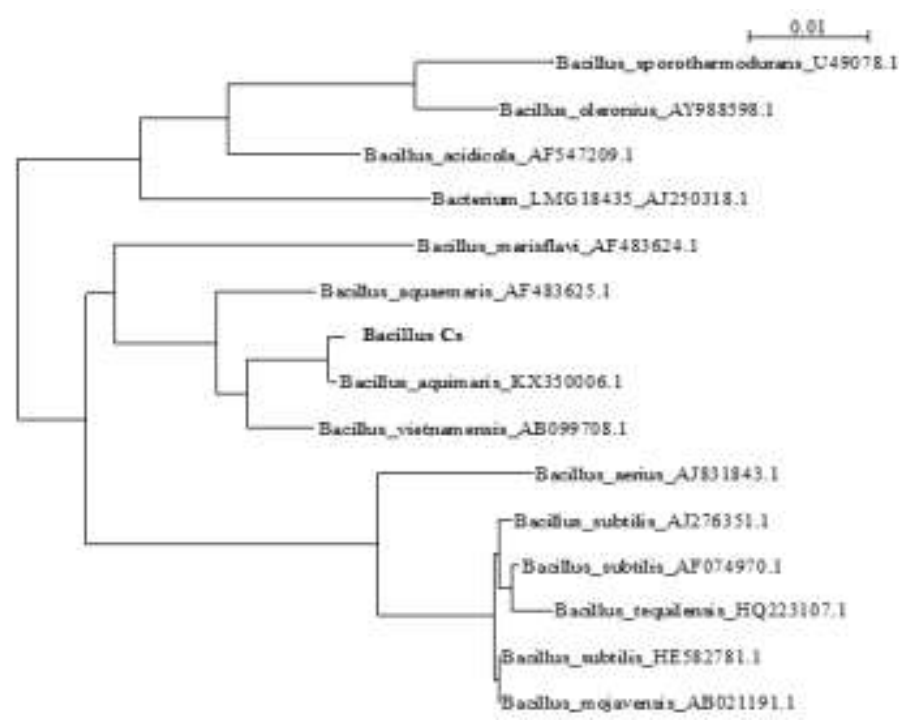

Fig. 3: Phylogenic tree of the isolate Cs based on full 16S rRNA gene sequences using distance method.

\section{Quantitative assay of lipaseactivity}

Lipase activity was quantified for the obtained isolates under the same experimental conditions. The isolate Ish gave the highest activity as showed in Table 2.

Table 2: Enzyme activity of lipase produced by the isolates after 7 days.

\begin{tabular}{|c|c|}
\hline Isolate & Enzyme activity (U/ml) \\
\hline Ish & 0.554 \\
\hline Cb & 0.5 \\
\hline Cs & 0.33 \\
\hline Pink & 0.3 \\
\hline
\end{tabular}

\section{Effect of different nitrogen sources on production of lipase}

Two different nitrogen sources were used in production medium. The optimum result was with yeast extract given from two isolates (Ish, $\mathrm{Cb}$ ) and the result of enzyme activity with $\mathrm{KNO}_{3}$ was lower than that with yeast extract and the highest enzyme activity was with two isolates $\mathrm{Cb}$ and Ish as shown in Figure 4. 


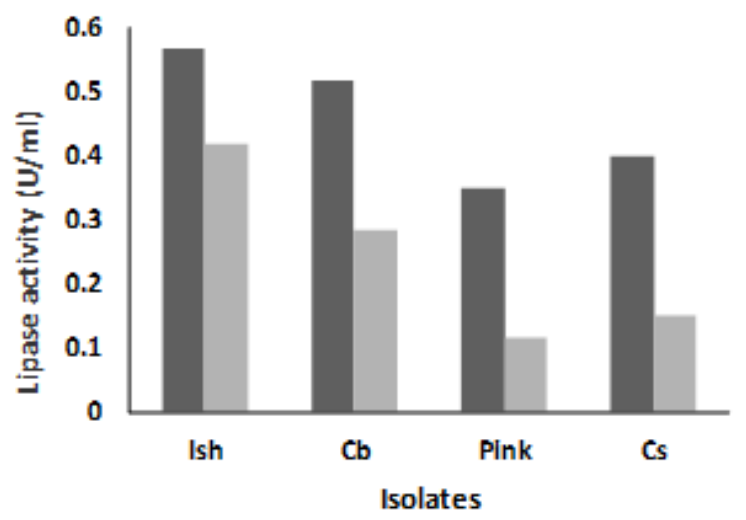

Fig.4: Effect of different nitrogen sources on lipase activity of different isolates. Black columns indicate lipase activity of the isolates with yeast extract as the organic nitrogen source and grey columns indicate lipase activity of the isolates with Potassium Nitrate as the inorganic nitrogen source.

\section{Time course of lipase activity "Growth versus lipase activity"}

Activity of the crude lipase enzyme and growth of highest lipase producing isolates (Ish, $\mathrm{Cb}$ ) on the culture was monitored for seven days (Figure 5-A\&B). The results in Figure 5 showed that the activity of the enzyme produced from the isolates Ish and $\mathrm{Cb}$ reached its maximum level at the third day and decreased again until the seventh day, while the growth significantly increased until the third day and then remained stable. In general, the growth and the enzyme activity of the isolate Ish were higher than those of the isolate $\mathrm{Cb}$.
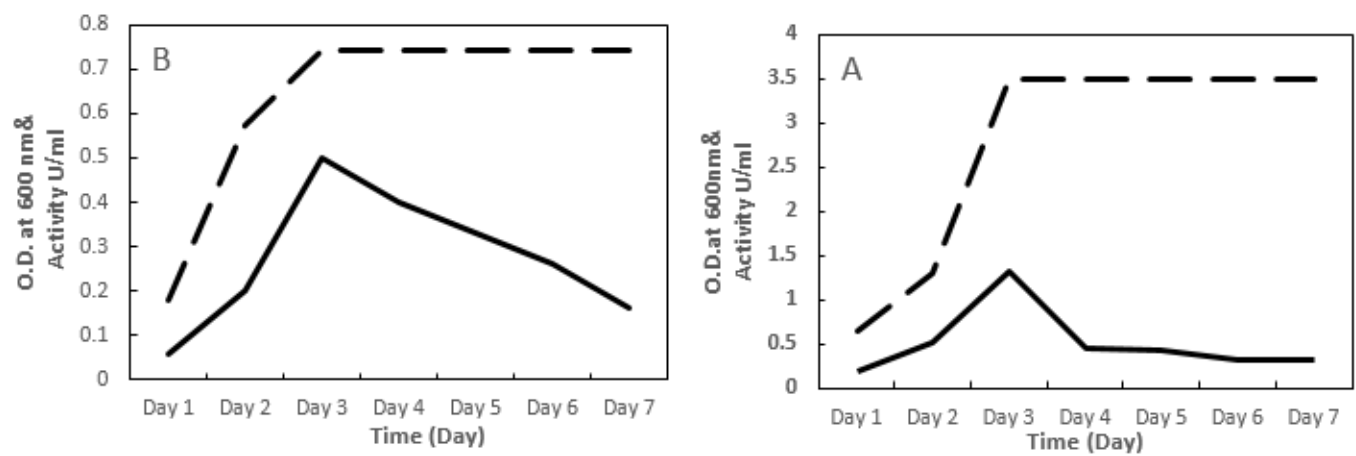

Fig. 5: Time course of lipase activity during growth. A) for isolate Piscibacillus_Ish and B) for isolate Halomonas_Cb. Growth is shown by the broken line and. enzyme activity is shown by solid line.

\section{Biodegradation of used cars oil}

According to the results of the enzyme activity, the isolates Ish and Cbhave been used to test their ability to degrade the used car oil. The weight of the residual oil was reduced in response to these isolates as indicated in Table 3.

Table 3: The weight of residual oil extracted from media and O.D. of the aqueous phase at $600 \mathrm{~nm}$.

\begin{tabular}{|c|c|c|c|}
\hline Isolate & Residual oil (gm) & O.D. at 600 (nm) & Percentage of degradation (\%) \\
\hline Control & 0.75 & - & - \\
\hline Ish & 0.42 & 2.43 & 44 \\
\hline Cb & 0.55 & 1.5 & 26.6 \\
\hline
\end{tabular}

The mostly degraded sample (the one treated with the isolate Ish) has been subjected to GC-MS analysis that showed a significant decrease in the oil fractions 
$\mathrm{C}_{18}, \mathrm{C}_{19}, \mathrm{C}_{21}, \mathrm{C}_{22}, \mathrm{C}_{27}, \mathrm{C}_{28}, \mathrm{C}_{32}$ and $\mathrm{C}_{39}$ by a percentage of $46.90 \%, 71.83 \%, 78.67 \%$, $20.14 \%, 62.21 \%, 74.60 \%, 35.84 \%$ and $91.95 \%$ respectively as shown in Table 4 and Figure 6. Shorter hydrocarbon fractions, which are $\mathrm{C}_{3}$ and $\mathrm{C}_{4}$, appeared in GC-MS analysis of the sample treated with the isolate Ish as shown in Figure 6. This strain degrades efficiently engine oil present at a concentration of $1 \%(\mathrm{v} / \mathrm{v})$, in the basal medium, at $37^{\circ} \mathrm{C}$ and in the presence of $13 \%(\mathrm{w} / \mathrm{v}) \mathrm{NaCl}$.

Table 4: Percentage $\%$ of degradation of hydrocarbon fractions of used engine oil by the isolate Ish analyzed from GC-Mass analysis.

\begin{tabular}{|c|l|l|c|c|}
\hline $\begin{array}{c}\text { Chain } \\
\text { Length }\end{array}$ & \multicolumn{1}{|c|}{$\begin{array}{c}\text { Molecular } \\
\text { Formula }\end{array}$} & \multicolumn{1}{|c|}{ Compound Name } & $\begin{array}{c}\text { Molecular } \\
\text { Weight }\end{array}$ & $\begin{array}{c}\text { \% of } \\
\text { degradation }\end{array}$ \\
\hline $\mathrm{C}_{7}$ & $\mathrm{C}_{7} \mathrm{H}_{16} \mathrm{O}$ & Pentane, 1ethoxy & 116 & 100 \\
\hline $\mathrm{C}_{14}$ & $\mathrm{C}_{14} \mathrm{H}_{22} \mathrm{O}$ & Phenol, 2,4bis(1,1dimethylehyl) & 206 & 100 \\
\hline $\mathrm{C}_{15}$ & $\mathrm{C}_{15} \mathrm{H}_{32}$ & Pentadecane & 212 & 100 \\
\hline $\mathrm{C}_{18}$ & $\mathrm{C}_{18} \mathrm{H}_{35} \mathrm{NO}_{2}$ & cis9,10Epoxyoctadecanamide & 297 & 46.90 \\
\hline $\mathrm{C}_{19}$ & $\mathrm{C}_{19} \mathrm{H}_{22} \mathrm{O}_{6}$ & Isochiapin B & 346 & 71.83 \\
\hline $\mathrm{C}_{21}$ & $\mathrm{C}_{21} \mathrm{H}_{36}$ & 14-á-H-Pregna & 288 & 78.67 \\
\hline $\mathrm{C}_{22}$ & $\mathrm{C}_{22} \mathrm{H}_{46}$ & Docosane & 310 & 20.14 \\
\hline $\mathrm{C}_{27}$ & $\mathrm{C}_{27} \mathrm{H}_{56} \mathrm{O}_{5}$ & Dimethoyglyceroldocosyl ether & 460 & 62.21 \\
\hline $\mathrm{C}_{28}$ & $\mathrm{C}_{28} \mathrm{H}_{43} \mathrm{NO}_{6}$ & (5á)Pregnane3,20ádio 1 & 489 & 74.60 \\
\hline $\mathrm{C}_{32}$ & $\mathrm{C}_{32} \mathrm{H}_{66}$ & Dotriacontane & 450 & 35.84 \\
\hline $\mathrm{C}_{35}$ & $\mathrm{C}_{35} \mathrm{H}_{70}$ & 17-Pentatriacontene & 490 & 100 \\
\hline $\mathrm{C}_{39}$ & $\mathrm{C}_{39} \mathrm{H}_{76} \mathrm{O}_{3}$ & Oleic acid,3(octadecyloxy)propyl ester & 592 & 91.95 \\
\hline
\end{tabular}

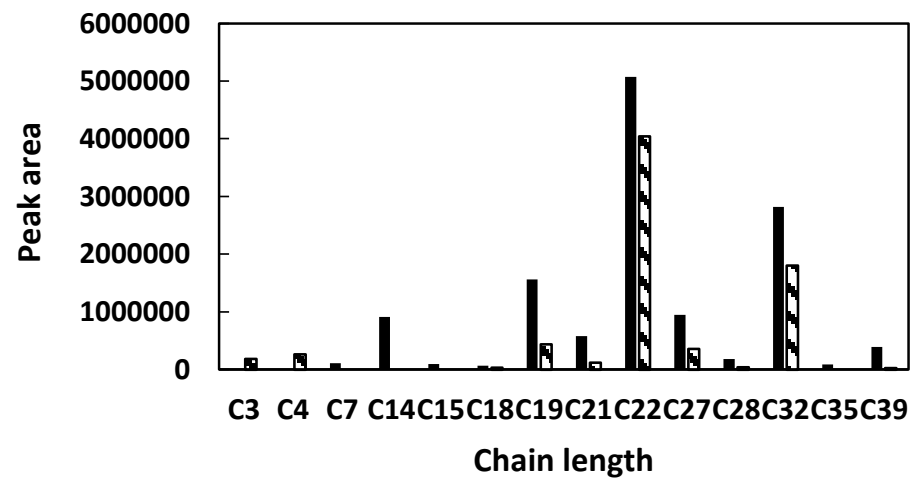

Fig. 6: Degradation of hydrocarbon fractions of the used engine oil by the isolate Ish analyzed from GC-Mass analysis. Dashed columns indicate hydrocarbon fractions of treated oil with Ish and Black columns indicate hydrocarbon fractions of the control.

\section{Textile dye degradation test}

The four isolates (Pink, $\mathrm{Cb}, \mathrm{Cs}$ and Ish) degraded the Indigo dye after 15 days in the medium containing: (1\% Indigo dye, $0.2 \%$ yeast extract and $10 \% \mathrm{NaCl}$ dissolved in $100 \mathrm{ml}$ sea water) but in the other media in whichinorganic nitrogen source $\mathrm{NaNO}_{3}$ was used neither de-colorization nor growth have been observed. The highest percentage of de-colorization was obtained with the isolate $\mathrm{Cb}$ by greater than $77 \%$ within 15 days under static incubation conditions as shown in Figure 7. 


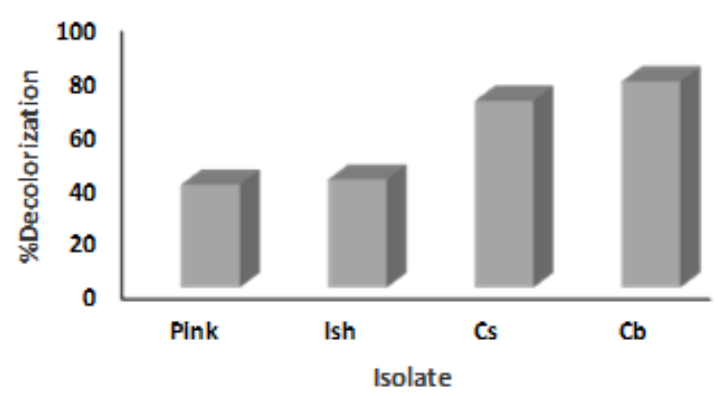

Fig. 7: The percentage of de-colorization of Indigo dye by the isolates.

\section{DISCUSSION}

The production of enzymes over a very wide range of salinities by moderate halophiles make them very attractive for research and for screening of novel enzymes with unusual properties ( $\mathrm{Li} \& \mathrm{Yu}, 2012$ ). In this study, four moderate halophiles have been isolated from the northern coast of the Mediterranean Sea in Egypt. These isolates have been selected among 16 for their ability to produce lipases with higher activity. Additionally, biochemical characterization of these strains showed that they could also produce other hydrolytic enzymes as cellulase, amylase and protease, which could be targets for further studies.

The isolates Ish and Pink were phylogenetically relevant to Piscibacillus halophilus that has been isolated previously from hypersaline lakes and featured by its ability to degrade casein and Tween 80 (Amoozegar et al., 2009). The analysis of the 16S rRNA showed that the isolate Cs is relevant to Bacillus aquimaris the isolate that has been obtained from Kumta coast as a halotolerantstrain which has an ability to produce extracellular halotolerant protease(Shivanand \& Jayaraman, 2009). The isolate $\mathrm{Cb}$ was found to be close phylogenetically to Halomonas merediana which is considered as moderate halophiles and it has been used as a source of $\alpha$ amylase(Coronado et al., 2000).

Nitrogen sources play an important role in the synthesis of lipase enzyme. In the present study, $0.2 \%$ of yeast extract was identified as the best nitrogen source was optimized as represented by other co-workers (Sivasubramani et al., 2013). It was reported that olive oil in combination with other nitrogen sources enhanced the lipase production, but in the presence of carbon source olive oil decreased the biomass content and lipase activity. It was also reported that organic nitrogen sources were found to increase lipase synthesis by Candida rugosa grown in the presence of olive oil (Fadıloğlu \& Erkmen, 1999).

Lipase production of the strains Ish and $\mathrm{Cb}$ were the highest between the isolates so they were selected to test the effect of time course on their lipase production. They produced lipase from the early-exponential phase of bacterial growth and reached their maximum level at the end of exponential phase like other moderate halophiles, such as, Marinobacter lipolyticus, Salinivibrio sp. strain SA-2 and Thalassobacillu ssp. strain DF-E4 (Amoozegar, et al., 2008; Lvet al., 2011).

In the stationary phase, growth was still stationary, but enzyme activity decreased. It was possible that the enzyme lost activity due to the high concentration of end product (product inhibition) (Kanlayakrit \& Boonpan, 2007).

Organisms belonging to various genera such as Marinobacter, Halomonas, Haloferax, Halobacterium and Haloarcula have been shown to degrade hydrocarbons (Fathepure, 2014). Up to our knowledge, there is no previous report about the ability 
of Piscibacillus halophilus or any relevant species to degrade hydrocarbons until the results that has been shown by the isolate Ish, which has been identified as Piscibacillus with close relevance to Piscibacillus halophilus. However, Halomonas merediana that is phylogenetically relevant to the isolate Cbhas been reported among others in a consortium to degrade hydrocarbons (Cui, et al.,2008).

The isolate Ish exhibited the higher growth on the oil and the lower weight of residual oil than the isolate $\mathrm{Cb}$ so it was chosen for further analysis by GC-MS. Certain hydrocarbons such as $\mathrm{C}_{19}, \mathrm{C}_{21}, \mathrm{C}_{27}, \mathrm{C}_{28}$ and $\mathrm{C}_{39}$ reduced drastically by day 20 . The disappearance of hydrocarbon fractions; $\mathrm{C}_{7}, \mathrm{C}_{15}$ and $\mathrm{C}_{35}$ on day 20 suggests that these may be saturated linear alkanes, so they are easily degraded or fragmented into shorter fractions which are $\mathrm{C}_{3}$ and $\mathrm{C}_{4}$ that appeared in the sample treated with Ish isolate.(Obayori, et al., 2014).

Organic nitrogen sources are considered essential media supplements for the regeneration of NADH that acts as an electron donor for the reduction of dyes by microorganisms (Rajeswari, et al., 2011). Nitrogen sources used in this study were yeast extract and sodium nitrate $\left(\mathrm{NaNO}_{3}\right)$. Yeast extract showed a maximum decolorization, such as that reported by previous studies (Lalnunhlimi \& Krishnaswamy, 2016).

Azo-reductase is the enzyme which degrades azo-bond in textile dye and the azo-reductase gene has been identified in a number of bacteria namely Azospirillum brasilense, B. subtilis and B. stearothermophilus (Suzuki, et al., 2001). In this study, most of the isolates were from Bacillus group which correlate the previous studies.

Halomonassp strain GTW was isolated from coastal sediments contaminated by chemical wastewater. The optimal salinity for de-colorization was $10-20 \%(\mathrm{w} / \mathrm{v})$ of $\mathrm{NaCl}$ and in the presence of yeast extract. The exploitation of the salt-tolerant bacteria in bioremediation would be a great improvement of conventional biological treatment systems (Guo, et al., 2008).

\section{CONCLUSION}

The represented results indicates the ability to use the isolate Ish either alone or in combination with other isolate to degrade hydrocarbons of long and short chains. The obtained isolates in this study would be potential biotechnological tools for various processes such as degradation of textile dyes and products such as amylases and proteases.

\section{REFERENCES}

Amoozegar, M. A.; Salehghamari, E.; Khajeh, K.; Kabiri, M. and Naddaf, S. (2008). Production of an extracellular thermohalophilic lipase from a moderately halophilic bacterium, Salinivibrio sp. strain SA-2. J. Basic Microb., 48(3): 160167.

Amoozegar, M.; Sánchez-Porro, C.; Rohban, R.; Hajighasemi, M. and Ventosa, A. (2009). Piscibacillus halophilus sp. nov., a moderately halophilic bacterium from a hypersaline Iranian lake. Int. J. Syst. Evol. Microbiol., 59(12): 30953099.

Coronado, M.-J.; Vargas, C.; Hofemeister, J.; Ventosa, A. and Nieto, J. J. (2000). Production and biochemical characterization of an $\alpha$-amylase from the moderate halophile Halomonas meridiana. FEMS Microbiol. Lett., 183(1): 6771. 
Cui, Z.; Lai, Q.; Dong, C. and Shao, Z. (2008). Biodiversity of polycyclic aromatic hydrocarbon-degrading bacteria from deep sea sediments of the Middle Atlantic Ridge. Environ.Microbiol., 10(8): 2138-2149.

DasSarma, S. and DasSarma,P.(2012). "Halophiles." Els.

Dussault, H. (1955). An improved technique for staining red halophilic bacteria. J. of Bacteriol., 70(4): 484.

Fadıloğlu, S. and Erkmen, O. (1999). Lipase production by Rhizopus oryzae growing on different carbon and nitrogen sources. J. Sci. Food. Agric., 79(13): 19361938.

Fathepure, B. Z. (2014). Recent studies in microbial degradation of petroleum hydrocarbons in hypersaline environments. Front. Microbiol., 5: 173.

Guo, J.; Zhou, J.; Wang, D.; Tian, C.; Wang, P. and Uddin, M. S. (2008). A novel moderately halophilic bacterium for decolorizing azo dye under high salt condition. Biodegrad.,19(1): 15-19.

Gutiérrez, C. and González, C. (1972). Method for simultaneous detection of proteinase and esterase activities in extremely halophilic bacteria. Appl.Microbiol., 24(3): 516.

Irfan, M.; Safdar, A.; Syed, Q. and Nadeem, M. (2012). Isolation and screening of cellulolytic bacteria from soil and optimization of cellulase production and activity. Turk. J. of Biochem./Turk Biyokimya Dergisi, 37(3).

Kanlayakrit, W. and Boonpan, A. (2007). Screening of halophilic lipase-producing bacteria and characterization of enzyme for fish sauce quality improvement. Kasetsart Journal: Natural Science, 41: 576-585.

Khunt, M. and Pandhi, N. (2012). Purification and characterization of Lipase from extreme halophiles isolated from Little Rann of Kutch, Gujarat, India. Int. J. Life Sci. Pharma. Res., 2: 55-61.

Kumar, A.; Parihar, S.S. and Batra, N. (2012). Enrichment, isolation and optimization of lipase-producing Staphylococcus sp. from oil mill waste (Oil cake). Journal of Experimental Sciences.

Kushner, D. J. (1988). Physiology of halophilic eubacteria. Halophilic bacteria, 109138.

Lalnunhlimi, S. and Krishnaswamy, V. (2016). Decolorization of azo dyes (Direct Blue 151 and Direct Red 31) by moderately alkaliphilic bacterial consortium. Braz. J. of Microbiol., 47(1): 39-46.

Le Borgne, S.; Paniagua, D. and Vazquez-Duhalt, R. (2008). Biodegradation of organic pollutants by halophilic bacteria and archaea. J. of Mol.Microbiol. and Biotech., 15(2-3): 74-92.

$\mathrm{Li}, \mathrm{X}$. and $\mathrm{Yu}, \mathrm{H} .-\mathrm{Y}$. (2012). Characterization of a novel extracellular lipase from a halophilic isolate, Chromohalobacter sp. LY7-8. Afr. J. Microbiol. Res., 6(14): 3516-3522.

Lv, X.-Y.; Guo, L.-Z.; Song, L.; Fu, Q.; Zhao, K. and Li, A.-X. (2011). Purification and characterization of a novel extracellular carboxylesterase from the moderately halophilic bacterium Thalassobacillus sp. strain DF-E4. Ann. Microbiol., 61(2): 281-290.

Martinelle, M.; Holmquist, M. and Hult, K. (1995). On the interfacial activation of Candida antarctica lipase $\mathrm{A}$ and $\mathrm{B}$ as compared with Humicola lanuginosa lipase. Biochim. et Biophys. Acta (BBA)-Lipids and Lipid Metabolism, 1258(3): 272-276. 
Mohamedin, A. (1999). Isolation, identification and some cultural conditionsof a protease-producing thermophilic Streptomyces straingrown on chicken feather as a substrate. Int. biodeter. \& biodegr., 43(1-2), 13-21.

Mounguengui, S.; Attéké, C.; Tchinda, J. B. S.; Ndikontar, M. K.; Dumarcay, S. and Gérardin, P. (2014). Discoloration and biodegradation of two dyes by white-rot fungi Perreniporia tephropora MUCL 47500 isolated in Gabon. Int. J. of Curr. Microbiol. and Appl. Sci., 3(6): 731-741.

Obayori, O. S.; Ilori, M. O.; Adebusoye, S. A.; Oyetibo, G. O.; Omotayo, A. E. and Amund, O. O. (2009). Degradation of hydrocarbons and biosurfactant production by Pseudomonas sp. strain LP1. World J. of Microbiol. and Biotechnol., 25(9): 1615-1623.

Obayori, O. S.; Salam, L. B. and Ogunwumi, O. S. (2014). Biodegradation of fresh and used engine oils by Pseudomonasaeruginosa LP5. J. of Bioremedia. \& Biodegr., 5(1), 1.

Oren, A. (2002). Diversity of halophilic microorganisms: environments, phylogeny, physiology, and applications.J. Ind. Microbiol. and Biotechnol., 28(1): 56-63.

Rajeswari, K.; Subashkumar, R. and Vijayaraman, K. (2011). Biodegradation of mixed textile dyes by bacterial strains isolated from dyewaste effluent. Res. J. Environ. Toxicol., 5(2): 97-107.

Ramnath, L.; Sithole, B. and Govinden, R. (2017). Identification of lipolytic enzymes isolated from bacteria indigenous to Eucalyptus wood species for application in the pulping industry. Biotechnol. Rep., 15: 114-124.

Rodriguez-Valera, F.; Ruiz-Berraquero, F. and Ramos-Cormenzana, A. (1980). Short communication isolation of extremely halophilic bacteria able to grow in defined inorganic media with single carbon sources. Microbiol., 119(2): 535538.

Rohban, R.; Amoozegar, M. A. and Ventosa, A. (2009). Screening and isolation of halophilic bacteria producing extracellular hydrolyses from Howz Soltan Lake, Iran. J. of Ind. Microbiol. Biotechnol., 36(3): 333-340.

Rubin, B.and Dennis, E. A. (1997). Lipases-Part A. Biotechnology: Elsevier.

Sanchez-Porro, C.; Tokunaga, H.; Tokunaga, M. and Ventosa, A. (2007). Chromohalobacterjaponicus sp. nov., a moderately halophilic bacterium isolated from a Japanese salty food. Int. J. of Sys. and Evol. Microbiol., 57(10): 2262-2266.

Sánchez-Porro, C.; Martin, S.; Mellado, E. and Ventosa, A. (2003). Diversity of moderately halophilic bacteria producing extracellular hydrolytic enzymes. J. of App. Microbiol., 94(2): 295-300.

Shivanand, P.and Jayaraman, G. (2009). Production of extracellular protease from halotolerant bacterium, Bacillusaquimaris strain VITP4 isolated from Kumta coast. Process Biochem., 44(10): 1088-1094.

Sivasubramani, K. optimization of lipase from marine derived bacteria. Int. J. Curr. Microb. Appli. Sci.,2(4): 126-135.

Suzuki, Y.; Yoda, T.; Ruhul, A. and Sugiura, W. (2001). Molecular cloning and characterization of the gene coding for azoreductase from Bacillus sp. OY1-2 isolated from soil. J. of Biol. Chem., 276(12): 9059-9065.

Takamoto, T.; Shirasaka, H.; Uyama, H. and Kobayashi, S. (2001). Lipase-catalyzed hydrolytic degradation of polyurethane in organic solvent. Chem. Lett., 30(6): 492-493.

Venkatachalam, P.; Joby, N. G.and Krishnakumar, N. (2013). Enhanced photovoltaic characterization and charge transport of $\mathrm{TIO}_{2}$ nanoparticles/nanotubes 
composite photoanode based on indigo carmine dye-sensitized solar cells. J. of Sol-Gel Sci. and Techn., 67(3): 618-628.

Zhao, D.; Yang, H.; Chen, J.; Cheng, F.; Kumar, S. and Han, J. et al. (2017).

Development of the first gene expression system for Salinicoccus strains with potential application in bioremediation of hypersaline wastewaters. Appl. Microbiol. and Biotechnol., 101(19): 7249-7258.

\section{ARABIC SUMMARY}

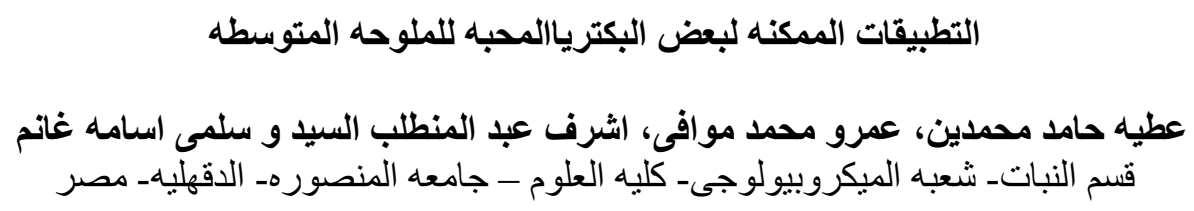

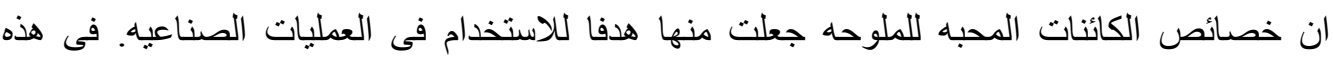

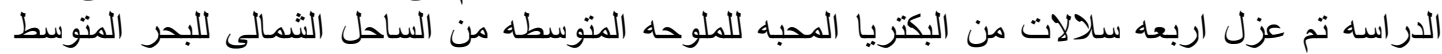

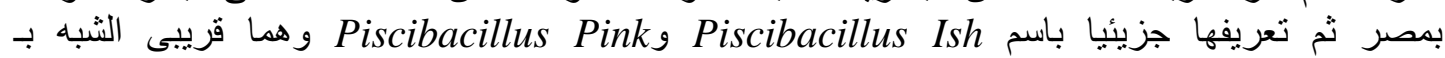

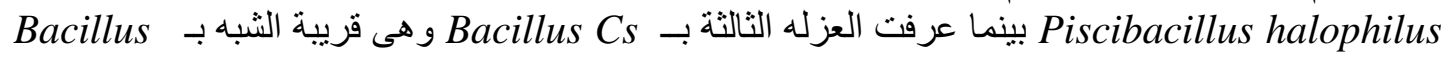

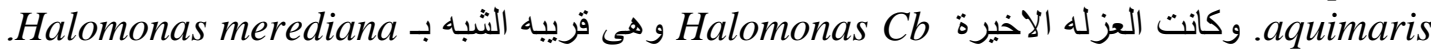

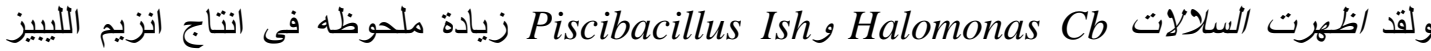

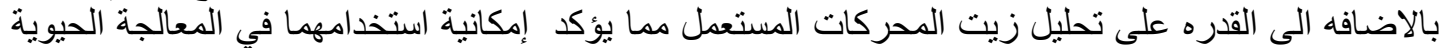

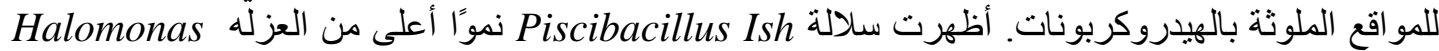

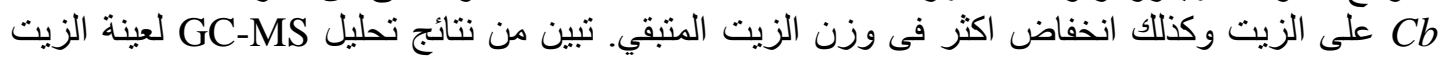

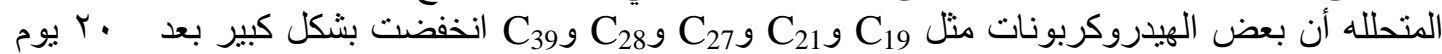

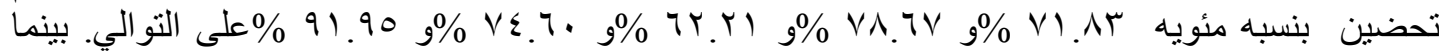
اختفاء الهيدروكربونات C C C C C C

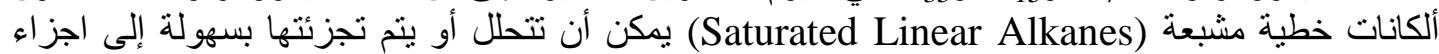

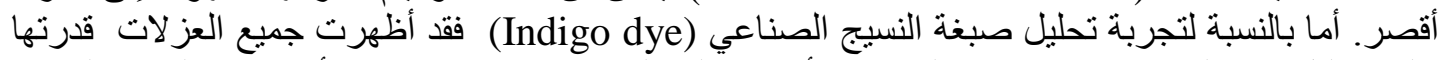

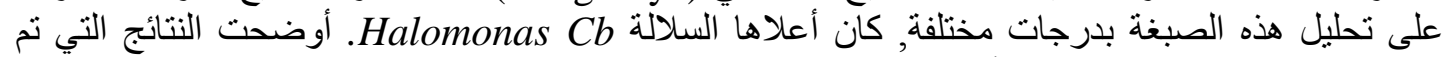

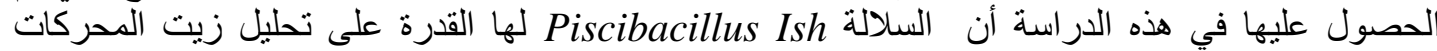
المستعملة وايضا قدره السلالة Halomonas Cb على المعالجة البيولوجية للنفايات السائلة لصناعات النسيج 